\title{
Adsorption of the Rhizosphere Bacterium Azospirillum brasilense Cd to Soil, Sand and Peat Particles
}

\author{
By YOAV BASHAN*† AND HANNA LEVANONY \\ Department of Plant Genetics, The Weizmann Institute of Science, Rehovot 76 100, Israel
}

(Received 2 October 1987; revised 8 December 1987)

\begin{abstract}
The rhizosphere bacterium Azospirillum brasilense $\mathrm{Cd}$ adsorbed strongly to light-texture and heavy-texture soils, but only slightly to quartz sand. Increase in clay and organic matter content, decrease in soil $\mathrm{pH}$, or flooding the soil enhanced adsorption, whereas the presence of a bacterial attractant, increase in soil $\mathrm{pH}$ or drying of the soil decreased adsorption. The cells adsorbed to the upper fraction of the soil profile, but were able to infiltrate deeper if very dry soil was wetted. Washing the soil did not desorb the bacteria from soil particles, but it did from the sand particles. Overwashing soil recovered relatively few cells, whereas overwashing sand detached most of the bacteria. Survival time of $A$. brasilense $\mathrm{Cd}$ was short in soil but long in peat inoculant.
\end{abstract}

\section{INTRODUCTION}

Inoculation of plants with Azospirillum brasilense $\mathrm{Cd}$ is usually done by application of the bacteria to the soil as near as possible to the germinating seedling (Albrecht et al., 1983; Bashan, $1986 a$ ). During this process the bacterium is exposed to the natural physical forces and interactions which prevail between soil bacteria and soil particles: adsorption, encapsulation by clay minerals, and wet and dry regimes in the soil (Marshall, 1971). To overcome these barriers and colonize plant roots the organism must create a substantial physical force to allow movement through the soil (Bashan, 1986c). Additionally, the bacteria can be transferred relatively large distances by biotic and abiotic vectors (Bashan \& Levanony, 1987). Azospirillum species colonize the roots of many plant species (Patriquin et al., 1983). However, the survival time of $A$. brasilense in soil, in the absence of plants, is relatively short (Albrecht et al., 1983; Bashan \& Levanony, 1987; Germida, 1986; Sadasivam et al., 1986; Smith et al., 1984).

The purpose of this study was to define the adsorption phenomena which occur upon application of bacteria to the soil, to characterize the main soil factors affecting the interaction between $A$. brasilense $\mathrm{Cd}$ and different soil and peat types, and to evaluate whether the bacteria are able to overcome these barriers to migration.

\section{METHODS}

Bacterial growth conditions and inoculation. A. brasilense Cd (ATCC 29710) was cultured on nutrient broth (Difco) medium (Bashan \& Levanony, 1985). Bacteria were washed twice with phosphate-buffered saline (PBS: $0.06 \mathrm{M}$-potassium phosphate, $0.15 \mathrm{M}$-sodium chloride) $\mathrm{pH} 7.2$ and inoculated into the soil columns by placing $1 \mathrm{ml}$ suspension (normally $10^{8}$ or $5 \times 10^{8}$ c.f.u. $\mathrm{ml}^{-1}$ ) on the soil surface. When lower bacterial concentrations were used, they were also diluted in PBS. Bacteria $\left(10^{8} \mathrm{ml}^{-1}\right)$ killed by exposure to similar $\gamma$-irradiation as the soil were also used.

Soil and peat types. The following soil and peat types were used: brown-red sandy soil (light-texture, Rehovot, Central Israel); loess soil (heavy-texture, Kibbutz Nir-Am, north-western Negev); pure silica quartz sand (Yeruham Crater, Central Negev, used in the glass industry); rendzina soil (Jordan Valley) (Ravikovitch, 1981); rough peat (Klasmann, FRG); and ground peat (40 mesh, Nitragin, Milwaukee, USA). The physicochemical characteristics of the soils and peat are summarized in Table 1. Soil and peat were used in both their natural state and after $\gamma$-irradiation ( $25 \mathrm{kGy}$ ), using a ${ }^{60} \mathrm{Co}$ source.

† Present address: Department of Agronomy, Ohio State University, Columbus, Ohio 43210, USA. 
Table 1. Characteristics of the soils and peat used in this study

Soil types are according to Ravikovitch (1981).

\begin{tabular}{|c|c|c|c|c|c|c|c|c|c|}
\hline \multirow[b]{3}{*}{ Soil/peat } & \multirow[b]{3}{*}{$\mathrm{pH}$} & \multicolumn{6}{|c|}{ Composition $(\%)$} & \multirow{3}{*}{$\begin{array}{c}\text { Field } \\
\text { capacity } \\
(\%)\end{array}$} & \multirow{3}{*}{$\begin{array}{l}\text { Predominant } \\
\text { clay types* }\end{array}$} \\
\hline & & \multirow[b]{2}{*}{ Clay } & \multirow[b]{2}{*}{ Silt } & \multicolumn{2}{|c|}{$\overbrace{}^{\text {Sand }}$} & \multirow{2}{*}{$\begin{array}{c}\text { Organic } \\
\text { matter }\end{array}$} & \multirow[b]{2}{*}{$\mathrm{CaCO}_{3}$} & & \\
\hline & & & & Fine & Coarse & & & & \\
\hline $\begin{array}{l}\text { Brown-red } \\
\text { sandy soil }\end{array}$ & $8 \cdot 1$ & $5 \cdot 7$ & $9 \cdot 1$ & $68 \cdot 1$ & $17 \cdot 1$ & 0.33 & $26 \cdot 8$ & $8 \cdot 6$ & M Ka Cal \\
\hline Loess & $8 \cdot 0$ & 19 & $18 \cdot 6$ & 62 & 0.4 & 0.74 & $15 \cdot 7$ & $17 \cdot 1$ & M Ka Cal I \\
\hline Rendzina soil & $8 \cdot 1$ & $35 \cdot 9$ & $29 \cdot 5$ & 24 & $10 \cdot 6$ & $2 \cdot 8$ & $43 \cdot 7$ & $41 \cdot 4$ & M Ka Cal I \\
\hline Silica quartz sand $\dagger$ & $7 \cdot 0-10 \cdot 0$ & 0.2 & - & $99 \cdot 7$ & - & $<0.01$ & Trace & $2 \cdot 0$ & $\mathbf{K a}$ \\
\hline Fine peat $\ddagger$ & $4 \cdot 1$ & 0 & 0 & 0 & 0 & 100 & $0 \cdot 01$ & - & - \\
\hline Coarse peat & $4 \cdot 5$ & 0 & 0 & 0 & 0 & 100 & - & - & - \\
\hline
\end{tabular}

* M, montmorillonite; Ka, kaolinite; Cal, calcite; I, illite.

† According to 'Fenizia' Co., Israel (S. Dolberg, personal communication). $\ddagger$ Nitragin Co.

Soil washing. Inoculated soil or peat was placed in a $50 \mathrm{ml}$ beaker, and sterile tap water was added until it formed a $1 \mathrm{~cm}$ layer on the soil surface. Four washing methods were used. The samples were stirred gently for $10 \mathrm{~s}$ or $2 \mathrm{~min}$, or soaked for $30 \mathrm{~min}$ without stirring and then stirred for $2 \mathrm{~min}$, or agitated in a vortex mixer (VortexGenie, Scientific Industries) at 180 r.p.m. for $60 \mathrm{~s}$. The stirring was then stopped for $10 \mathrm{~min}$, to allow sedimentation of soil particles. The supernatant was collected, and the number of $A$. brasilense $\mathrm{Cd}$ cells was determined by the improved selection technique (Bashan \& Levanony, 1985). The remaining soil was diluted serially in sterile tap water and the minimal number of adsorbed bacteria was determined (Foster, 1986). Cell counts from the soil and supernatant were combined for comparison with the initial bacterial concentration.

Changes in soil $p H$. Following determination of the initial soil $\mathrm{pH}$, soils were individually mixed with $\mathrm{Tris} / \mathrm{HCl}$ $(0.1 \mathrm{M})$ or citrate/acetate $(0.1 \mathrm{M})$ buffers to produce different soil $\mathrm{pH}$ values. The final soil $\mathrm{pH}$ was retested immediately before application of bacteria. Variations in $\mathrm{pH}$ were $\pm 0.2 \mathrm{pH}$ units.

Peat inoculant preparation. Peat inoculant was prepared (Thompson, 1980) by mixing $45 \mathrm{~g}$ ground peat with $5 \mathrm{~g}$ $\mathrm{CaCO}_{3}$ and $20 \mathrm{ml}$ tap water (final $\mathrm{pH} \mathrm{6.8)} \mathrm{in} \mathrm{polyethylene} \mathrm{bags} \mathrm{that} \mathrm{were} \mathrm{sealed} \mathrm{with} \mathrm{cotton} \mathrm{plugs.} \mathrm{The} \mathrm{bags} \mathrm{were}$ sterilized by $\gamma$-irradiation and $30 \mathrm{ml}$ of a $24 \mathrm{~h}$ bacterial culture (approximately $10^{9}$ c.f.u. $\mathrm{ml}^{-1}$ ) was aseptically added to each bag. The contents were mixed by shaking, incubated at $30 \pm 2{ }^{\circ} \mathrm{C}$, and re-mixed at $2 \mathrm{~d}$ intervals. The number of bacteria after $7 \mathrm{~d}$ incubation ranged from $5 \times 10^{8}$ to $10^{9}$ c.f.u. g inoculant ${ }^{-1}$ as determined by the improved selection technique (Bashan \& Levanony, 1985). Since the bacteria formed aggregates (Bashan et al., 1986) these numbers should be considered to be minimal numbers.

Preparation of beads containing attractant. Glycine $\left(10^{-2} \mathrm{M}\right.$ in distilled water) was mixed with $2 \%(\mathrm{w} / \mathrm{v})$ sodium alginate $(\mathrm{BDH})$. The beads that formed were lyophilized and maintained in sealed glass containers with silica gel until use (Bashan, 1986 ). Twenty-five beads were placed in each column. The controls contained alginate beads with no attractant.

Adsorption and infiltration assays of bacteria to soil and peat. Most experiments were done in soil columns made of soft polyethylene of various sizes, ranging from $0.5 \times 10 \mathrm{~cm}$ (smallest column) to $3 \times 50 \mathrm{~cm}$ (largest column). The upper and lower ends of each column were made of glass in order to facilitate connection of the flexible column to the water reservoir, as well as to the fraction collector. Each column was lightly packed (to avoid compaction) with soil, containing water at half field capacity, placed on a glass-wool layer. A second layer of glass-wool was placed in the upper part of the column to ensure equal dispersion of water throughout the column. When beads were used, they were placed either on the bottom glass-wool layer before soil insertion or in the middle of the column. $A$. brasilense $\mathrm{Cd}$ was inoculated $\left(0.5 \mathrm{ml}, 10^{9} \mathrm{c}\right.$.f.u. $\left.\mathrm{ml}^{-1}\right)$ beneath the upper glass-wool layer by Pasteur pipette, and the suspension was allowed to be adsorbed by the soil. After connecting the water reservoir to the column, fractions ( 1 to $5 \mathrm{ml}$ ) were collected, and the number of living and dead $A$. brasilense $C d$ cells was determined by specific enzyme-linked immunosorbent assay (ELISA) (Levanony et al., 1987). The number of fractions collected was controlled by stopping the water flow. The amount of water was normally equivalent to $100 \mathrm{~mm}$ of rainfall, but in some cases was larger. Alternatively, a continuous flow of water was applied. Collection was stopped after bacteria were absent from several consecutive fractions.

Distribution of $A$. brasilense $C d$ in columns. This was determined by transversely dividing each column into $0.5 \mathrm{~cm}$ thick sections, weighing the soil, and suspending it in PBS. The number of $A$. brasilense $C d$ was determined by ELISA. When the number of bacteria fell below the sensitivity of the ELISA $\left(<10^{4}\right.$ c.f.u. $\left.\mathrm{ml}^{-1}\right)$ a quantitative enumeration was made by the improved selection technique (Bashan \& Levanony, 1985), which is based on the 
Most Probable Number (MPN) method. To be counted by MPN, the bacteria adsorbed to soil particles were grown in a semi-solid nitrogen-free medium for $72 \mathrm{~h}$ at $30 \pm 2{ }^{\circ} \mathrm{C}$ (Bashan \& Levanony, 1985). Identification of $\boldsymbol{A}$. brasilense Cd in the MPN tubes was done by ELISA.

The infiltrating ability of $A$. brasilense $\mathrm{Cd}$ was tested in light-texture soil which was first dried $\left(45 \pm 1{ }^{\circ} \mathrm{C}, 48 \mathrm{~h}\right.$ in forced-draught oven), then packed into a column $(1 \times 15 \mathrm{~cm})$. Bacteria were applied onto the dried soil surface, then water was added until it filled the entire column. The distribution of the bacteria within the column was determined as described above, and the water content of each soil section was determined by drying the soil sections.

Adsorption of $A$. brasilense $\mathrm{Cd}$ to soil in the presence of bacterial attractants was tested in soil columns filled with sterile tap water at field capacity. The columns were then incubated for $48 \mathrm{~h}$ at $30 \pm 2{ }^{\circ} \mathrm{C}$ before water was eluted through the column. No detectable increase in the $A$. brasilense $\mathrm{Cd}$ population was observed. In addition, a washed bacterial suspension ( $10^{8}$ c.f.u.) was mixed with $5 \mathrm{~g}$ soil and incubated for 1 to $20 \mathrm{~d}$. The bacteria were counted in the soil particles or in the supernatant after washing as described above. The soil was flooded by adding sterile distilled water to give a $1 \mathrm{~cm}$ water layer on the soil surface. The samples were incubated for $48 \mathrm{~h}$ at $30 \pm 2{ }^{\circ} \mathrm{C}$ before determining bacterial adsorption. The effect of adding clay and organic matter on adsorption was tested by adding rendzina soil (total clay content $36 \%$ ) or loess soil (clay content $19 \%$ ) or fine peat to silica quartz sand prior to bacterial inoculation.

Survival experiments. Ten $20 \mathrm{~g}$ samples of each soil or peat were inoculated with $A$. brasilense Cd to a final concentration of $10^{8} \mathrm{c.f}$.u. (g soil) $)^{-1}$ and were kept aseptic in polyethylene bags sealed with cotton plugs at ambient temperature $\left(20\right.$ to $25^{\circ} \mathrm{C}$ ). Half of the peat inoculant bag samples were kept at $4 \pm 1{ }^{\circ} \mathrm{C}$. At selected intervals, $1 \mathrm{~g}$ samples from each bag were serially diluted in PBS and cell counts of $A$. brasilense Cd were made by the ELISA method and in peat samples by the improved selection technique (Bashan \& Levanony, 1985).

Experimental design and statistical analysis. All experiments were done in triplicate and repeated at least twice. All ELISA values were obtained in duplicate or triplicate wells. Statistical significance is indicated by $P \leqslant 0.05$ or by $\mathrm{SE}$ values.

\section{RESULTS}

Adsorption of live and dead A. brasilense Cd cells to various soils. Two concentrations of $A$. brasilense Cd cells were used to determine the ability of this bacterium to adsorb onto the four different soil types. Adsorption was measured by the two different methods of bacterial emuneration. In heavy-texture (loess and rendzina) and light-texture (brown-red sandy) soils relatively small numbers of bacteria were recovered from the columns (Table 2), indicating that most bacteria were adsorbed by the soil. When low concentrations of $A$. brasilense $\mathrm{Cd}$ were applied to light-texture soil, they were all adsorbed. However, the very-light-texture soil (pure quartz sand) failed to adsorb $A$. brasilense Cd (Table 2). The percentage of dead bacteria adsorbed by light-texture soil was significantly less than that of live bacteria (Table 3 ). The condition of the soil, whether natural or sterilized, had no effect on bacterial adsorption (Table 3).

Strength of $A$. brasilense $C d$ adsorption to soil and peat. Washing inoculated peat and soils caused little bacterial release (Table 4), and most of the bacteria applied were adsorbed to the substrates. However, washing released many of the bacteria from the quartz particles. The greater the number of washings the more bacteria were released (Table 4).

Adsorption site of $A$. brasilense $C d$ in soil columns. Following application of $A$. brasilense Cd to soil columns, the soil was washed, the columns were sectioned and the number of bacteria in each section was determined. In the heavy-texture soil, $A$. brasilense $\mathrm{Cd}$ cells were located in the upper soil fractions no deeper than $20 \mathrm{~mm}$ from the application site, whereas in the light-texture soil small numbers of bacteria were found slightly deeper (Fig. 1). A. brasilense Cd was detected throughout the column filled with quartz sand and cells were concentrated at a depth of 50 to $100 \mathrm{~mm}$ from the application site (Fig. 1). When the columns were overwashed (equivalent to $3000 \mathrm{~mm}$ of rain), few bacteria were recovered from the soil, whereas nearly all bacteria were washed from the sand (Table 2).

Infiltration of $A$. brasilense $C d$ into dry soil. Application of bacteria to dry light-texture soil resulted in their adsorption in the first $50 \mathrm{~mm}$ of the column (Fig. 2). Few bacteria reached a depth of $90 \mathrm{~mm}$, although the water front reached the column end (150 $\mathrm{mm}$ from the top) (Fig. 2). Cells applied to dry soil reached deeper levels than those applied to wet soil (cf. Figs 1 and 2). 
Table 2. Adsorption of A. brasilense Cd to various soil types

Soil types are according to Ravikovitch (1981). Soils were sterilized by $\gamma$-irradiation (25 kGy).

\begin{tabular}{|c|c|c|c|c|}
\hline \multirow[b]{2}{*}{ Soil type } & \multirow[b]{2}{*}{$\begin{array}{l}\text { No. of applied } \\
\text { bacteria } \\
\text { (c.f.u.) }\end{array}$} & \multicolumn{2}{|c|}{$\begin{array}{l}\text { Total no. of bacteria released } \\
\text { from } 10 \times 1 \mathrm{~cm} \text { soil column }\end{array}$} & \multirow[b]{2}{*}{$\begin{array}{l}\text { Adsorption } \\
\text { to soil } \\
(\%)\end{array}$} \\
\hline & & $\begin{array}{l}\text { Semi-selective } \\
\text { medium } \dagger\end{array}$ & ELISA $\ddagger$ & \\
\hline \multirow[t]{2}{*}{$\begin{array}{l}\text { Brown-red } \\
\text { sandy soil }\end{array}$} & $10^{8}$ & $1.80 \pm 0.4 \times 10^{7}$ & $0.60 \pm 0.2 \times 10^{7}$ & 82 \\
\hline & $10^{6}$ & 0 & ND & 100 \\
\hline \multirow{2}{*}{ Pure silica quartz } & $10^{8}$ & $9.60 \pm 0.1 \times 10^{7}$ & $9 \cdot 10 \pm 0.3 \times 10^{7}$ & 4 \\
\hline & $10^{6}$ & $9.40 \pm 0.3 \times 10^{5}$ & ND & 6 \\
\hline Loess soil & $10^{8}$ & $1 \cdot 10 \pm 0.3 \times 10^{6}$ & $0.90 \pm 0.2 \times 10^{6}$ & 99 \\
\hline \multirow[t]{2}{*}{ Rendzina soil } & $10^{8}$ & $1.60 \pm 0.4 \times 10^{6}$ & $1.20 \pm 0.3 \times 10^{6}$ & 99 \\
\hline & $\begin{array}{l}\text { ND, Not de } \\
* 1 \text { ml bact } \\
\dagger \text { Accordin } \\
\ddagger \text { Accordin }\end{array}$ & $\begin{array}{l}\text { suspension added } \\
\text { ashan and Levan } \\
\text { evanony et al. (1) }\end{array}$ & $\begin{array}{l}\text { olumn. } \\
\text { 985). }\end{array}$ & \\
\hline
\end{tabular}

Table 3. Adsorption of live and dead cells of A. brasilense Cd to brown-red sandy soil* Values followed by different letters differ significantly at $P \leqslant 0.05$.

\begin{tabular}{|c|c|c|c|}
\hline \multirow{2}{*}{$\begin{array}{l}\text { Bacterial } \\
\text { condition }\end{array}$} & \multirow{2}{*}{$\begin{array}{c}\gamma \text {-Irradiation } \\
(25 \mathrm{kGy}) \\
\text { of soil }\end{array}$} & \multicolumn{2}{|c|}{$\begin{array}{l}\text { Adsorbed c.f.u. } \\
\text { determined by ELISA } \dagger\end{array}$} \\
\hline & & No. & $\%$ \\
\hline Live & + & $\begin{array}{l}8 \cdot 50 \pm 0.4 \times 10^{7} \\
8 \cdot 10 \pm 0.5 \times 10^{7}\end{array}$ & $\begin{array}{l}85^{a} \\
81^{a}\end{array}$ \\
\hline Dead & $\begin{array}{l}+ \\
-\end{array}$ & $\begin{array}{l}6 \cdot 10 \pm 0.4 \times 10^{7} \\
5.60 \pm 0.5 \times 10^{7}\end{array}$ & $\begin{array}{l}61^{b} \\
56^{b}\end{array}$ \\
\hline
\end{tabular}

* $10^{8}$ c.f.u. A. brasilense in the exponential phase of growth were applied to $5 \mathrm{~g}$ soil. $\dagger$ According to Levanony et al. (1987).

\section{Table 4. Number of A. brasilense Cd cells adsorbed to sterile soil and peat following different methods of soil washing}

Soil samples $(5 \mathrm{~g})$ were inoculated with $1 \mathrm{ml}$ bacterial suspension containing $10^{8} \mathrm{c}$.f.u. Soils were washed $48 \mathrm{~h}$ after inoculation. The number of bacteria in the supernatants was measured by the improved selection technique of Bashan and Levanony (1985). Values given are the means of five replicates. ND, Not detected.

Soil washing method

(a) Not washed

(b) Rinsed for $10 \mathrm{~s}$ with slow stirring

(c) Washed for 2 min with slow stirring

(d) Soaked for 30 min then washed as in $(c)$

(e) Rinsed as in (b) then vortex-mixed for $60 \mathrm{~s}$

\begin{tabular}{|c|c|c|c|c|c|}
\hline \multicolumn{6}{|c|}{ No. of bacteria $\mathrm{g}^{-1}$} \\
\hline \multicolumn{2}{|c|}{ Brown-red sandy soil } & \multicolumn{2}{|c|}{ Silica quartz sand } & \multicolumn{2}{|c|}{ Fine peat } \\
\hline Supernatant & Sediment & Supernatant & Sediment & Supernatant & Sediment \\
\hline ND & $10^{8}$ & ND & $10^{8}$ & ND & $9.7 \times 10^{8}$ \\
\hline $0.3 \times 10^{7}$ & $9.0 \times 10^{7}$ & $9.6 \times 10^{7}$ & $4.2 \times 10^{5}$ & $0.2 \times 10^{6}$ & $9.4 \times 10^{7}$ \\
\hline $0.5 \times 10^{7}$ & $8.9 \times 10^{7}$ & $9.4 \times 10^{7}$ & $2 \cdot 1 \times 10^{2}$ & $0.4 \times 10^{6}$ & $9 \cdot 1 \times 10^{7}$ \\
\hline $0.7 \times 10^{7}$ & $8.2 \times 10^{7}$ & $9.7 \times 10^{7}$ & $1.7 \times 10^{2}$ & $0.5 \times 10^{6}$ & $9 \cdot 2 \times 10^{7}$ \\
\hline $0.9 \times 10^{7}$ & $8.0 \times 10^{7}$ & $9.7 \times 10^{7}$ & $8.0 \times 10^{1}$ & $0.4 \times 10^{6}$ & $9.3 \times 10^{7}$ \\
\hline
\end{tabular}




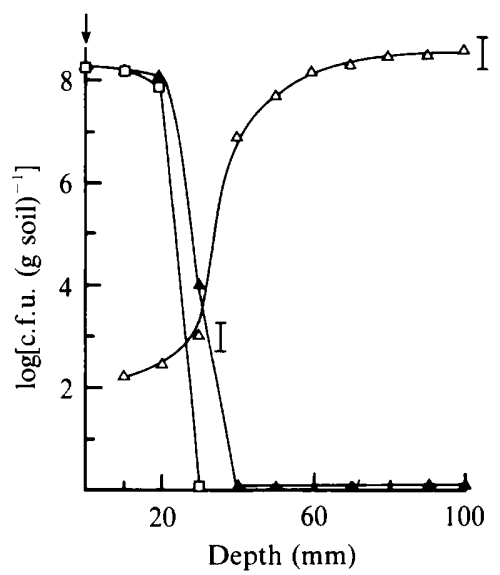

Fig. 1

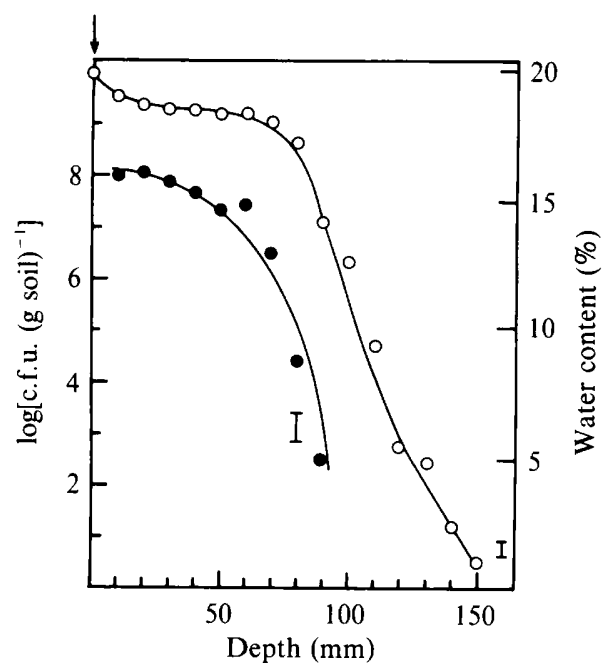

Fig. 2

Fig. 1. Adsorption sites of $A$. brasilense $\mathrm{Cd}$ at various soil depths after application of bacteria onto the soil surface (arrow). $\boldsymbol{\Delta}$, Brown-red sandy soil; $\triangle$, silica quartz sand; $\square$, loess soil. Bars represent SE.

Fig. 2. Infiltration of $A$. brasilense $\mathrm{Cd}$ into dry brown-red sandy soil after application onto the soil surface (arrow). No. of bacteria; $O$, water content. Bars represent SE.

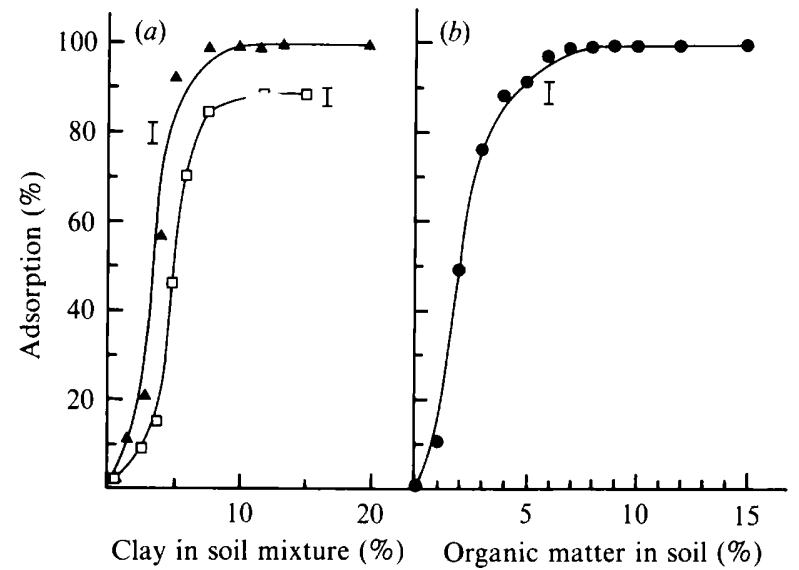

Fig. 3. Adsorption of A. brasilense Cd to soil mixtures. (a) Addition of loess soil ( $\square$ ) and rendzina soil (A) to sand, (b) addition of fine peat. Bars represent SE.

Effect of clays and organic matter on bacterial adsorption. Addition of clays from light-texture or heavy-texture soil to sand resulted in a marked increase in the adsorption of $A$. brasilense Cd. Maximal adsorption was observed when the total clay content in the formed soil was $5 \%$ or greater (Fig. $3 a$ ). Similar results were obtained when organic matter (fine peat) was added (Fig. $3 b)$.

Effect of $p H$ on adsorption of $A$. brasilense $C d$ to soil. Regardless of the soil type, decreasing soil $\mathrm{pH}$ increased adsorption, whereas increasing soil $\mathrm{pH}$ decreased adsorption (Fig. 4). This effect was most marked in light-texture soil.

Adsorption of $A$. brasilense $C d$ to soil in the presence of a bacterial attractant. Beads containing glycine as attractant were added to soil columns at two depths. When the attractant was placed 


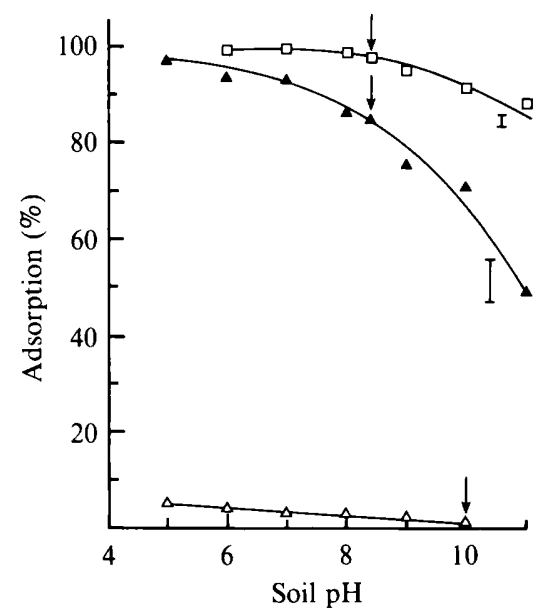

Fig. 4

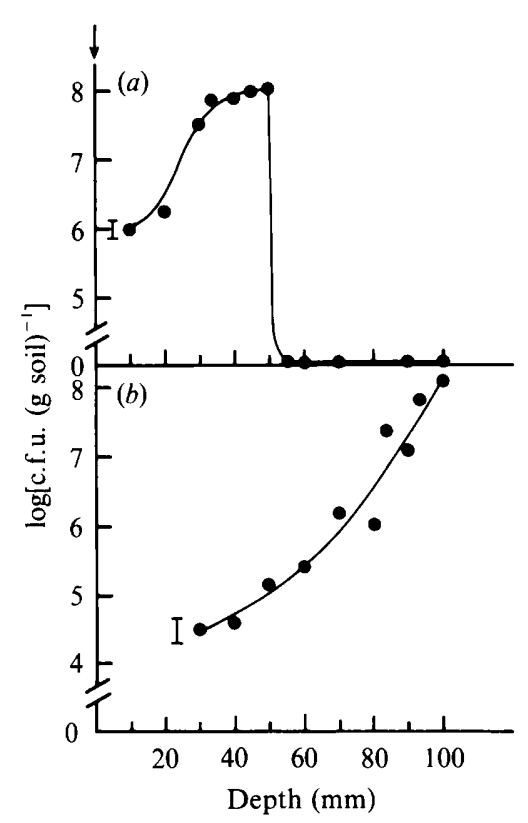

Fig. 5

Fig. 4. Effect of soil pH on adsorption of $A$. brasilense $\mathrm{Cd}$. $\square$, Loess soil; $\boldsymbol{\Delta}$, brown-red sandy soil ; $\triangle$, silica quartz sand. Arrows indicate the normal $\mathrm{pH}$ of the soil; bars represent SE.

Fig. 5. Adsorption of $A$. brasilense $\mathrm{Cd}$ to brown-red sandy soil containing bacterial attractant $\left(10^{-2} \mathrm{M}\right.$ glycine in beads) at a depth of $50 \mathrm{~mm}(a)$ or $100 \mathrm{~mm}(b)$. Arrow indicates bacterial application site. Bars represent SE.

at a depth of $50 \mathrm{~mm}$ most of the applied bacteria accumulated close to this site (Fig. $5 a$ ). When the attractant was placed at the bottom of the column, bacteria were detected at a depth of $30 \mathrm{~mm}$ but the majority were observed close to the site of the attractant (Fig. $5 b$ ).

Adsorption of $A$. brasilense Cd to soil and peat after flooding. After a period of flooding, the percentage adsorption of $A$. brasilense Cd increased in three types of soils and in two types of peat (Fig. 6), probably as a result of multiplication of the bacteria during flooding. No detectable difference was found between the soils and the peat. However, bacterial adsorption to sand, even after flooding, was very low (Fig. 6).

Survival of $A$. brasilense $C d$ in soils and peat. Survival of $A$. brasilense $\mathrm{Cd}$ in the three types of soil was low: after $9 \mathrm{~d}$ in heavy-texture soil, $15 \mathrm{~d}$ in light-texture soil, and $20 \mathrm{~d}$ in sand, the bacteria were almost undetectable (Fig. 7). In peat, however, the cells multiplied, reaching maximal population size after $10 \mathrm{~d}$ (Fig. 7). Thereafter the population decreased, especially in inoculants incubated at room temperature. The populations were stable from 30 to $150 \mathrm{~d}$ after inoculation, survival being relatively higher in the cold (Fig. 7). Because $A$. brasilense Cd adsorbs to soil and peat particles, the bacterial numbers demonstrated here should be considered as minimal numbers; the true population size was possibly greater.

\section{DISCUSSION}

Interactions between bacteria and soil particles can be divided into three different types: (i) bacterial adsorption onto the surfaces of large soil particles; (ii) adsorption of bacteria to soil particles of similar size, forming aggregates; and (iii) adsorption of very small particles onto the surfaces of bacteria. The ability of different soils to adsorb bacteria depends primarily on the mechanical composition of the soil and less on the species and growth conditions of the bacteria 


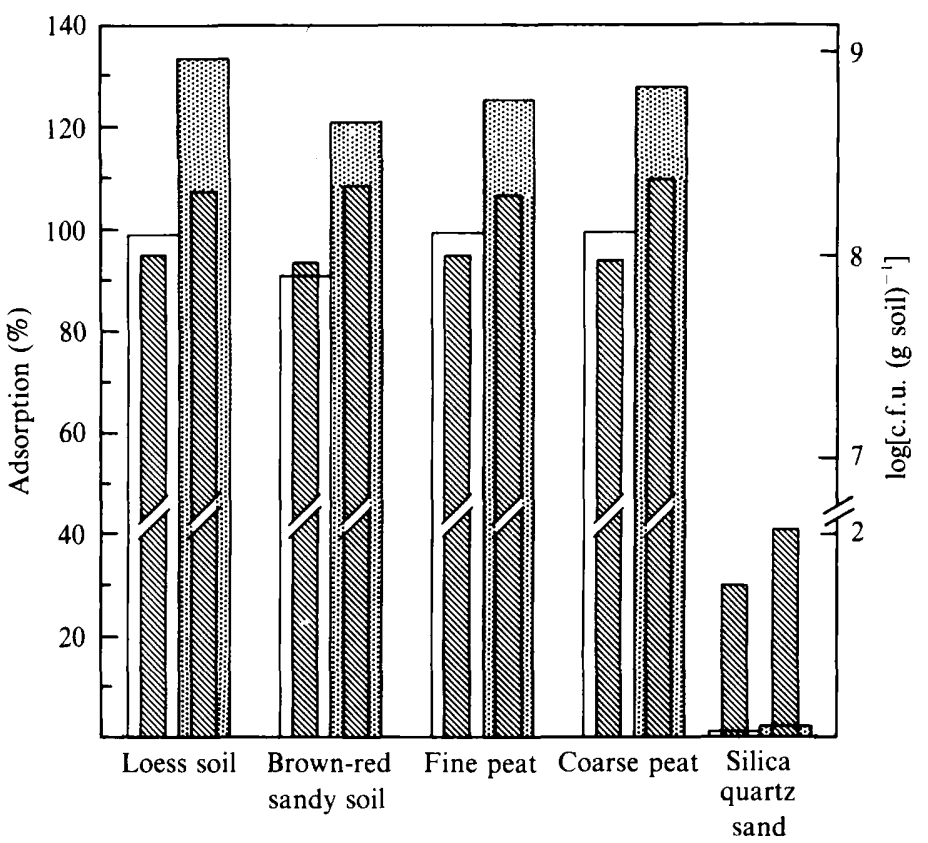

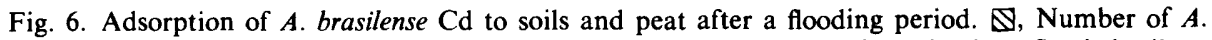
brasilense $\mathrm{Cd}$; , percentage adsorption in flooded soil; $\square$, percentage adsorption in unflooded soil.

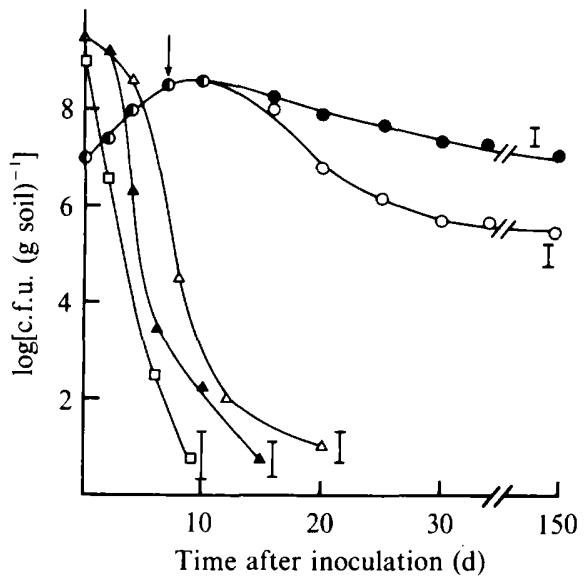

Fig. 7. Survival of $A$. brasilense $C d$ in soils and peat. $\square$, Loess soil; $\Delta$, brown-red sandy soil; $\triangle$, silica quartz sand; $O$, fine peat inoculant incubated at ambient temperature $\left(20-25^{\circ} \mathrm{C}\right)$; $\bigcirc$, fine peat inoculant transferred to $4 \pm 1{ }^{\circ} \mathrm{C}$ (arrow) after incubation at ambient temperature for $8 \mathrm{~d}$. Bars represent SE.

(Lynch \& Bragg, 1985; Marshall, 1971; Marshall \& Bitton, 1980). Bacteria and soil particles (clays and organic matter) possess a similar net negative surface charge (Marshall, 1967), which prevents direct contact and raises the question of how bacteria adsorb to these particles (Marshall, 1975). When soil-origin bacteria are reapplied to soil, the majority adsorb to soil particles but few adsorb to sand particles (Daniels, 1980; Marshall, 1971; Peele, 1936; Rubentschik et al., 1936); both dead and living cells adsorb in a similar fashion (Santoro \& Stotzky, 1968). The number of adsorbed symbiotic rhizosphere bacteria (Rhizobium sp.) is much 
lower than that of soil bacteria [about $10^{5}$ cells (g soil) ${ }^{-1}$ ] (Daniels, 1980). The number of associative rhizosphere bacteria adsorbed to soil has not yet been elucidated. We have shown that adsorption to soil of living cells of the typical rhizosphere bacterium $A$. brasilense $\mathrm{Cd}$ resembled that of soil bacteria, whereas fewer dead cells were adsorbed. Our study suggests that adsorption to soil of $A$. brasilense $\mathrm{Cd}$ can be characterized by terms previously used for soil bacteria generally.

Bacteria that reach the soil-particle surface are subject to short-range attraction forces (hydrophobic, van der Waals and electrostatic forces) that are capable of weakly holding the bacteria close to the surface. Desorption of soil bacteria from soil particles by external mechanical forces, such as shaking and washing, is difficult (Rubentschik et al., 1936). A. brasilense $\mathrm{Cd}$ was strongly and permanently adsorbed to soils containing small particles and to organic matter. Application of an external washing force, even in excess, removed few bacteria. However, these washings, and especially overwashings, desorbed bacteria adhered to rough sand, indicating that adsorption of $\boldsymbol{A}$. brasilense Cd to sand is relatively weak.

The distribution of soil bacteria within the soil is not homogeneous (Siala et al., 1974): the relative penetration of bacterial cells depends primarily on whether they are strongly adsorbed to the solid particles, or restricted in their flow through small soil channels, or on the availability of water (Bitton et al., 1974; Griffin \& Quail, 1968; Mudd \& Mudd, 1924; Parke et al., 1986). Rhizosphere Azospirillum species are usually artificially applied to the soil, and are not part of the natural soil microflora in several ecosystems (Bashan, $1986 a$; Smith et al., 1984). Contrary to soil bacteria, distribution of $A$. brasilense $\mathrm{Cd}$ in soil was homogeneous and restricted to the application site, as previously demonstrated in brown-red sandy soil (Bashan, 1986c). The adsorption forces and polymer bridging in the soil (unpublished) hold $\boldsymbol{A}$. brasilense Cd permanently, despite the force created by a water stream, which has little effect on the distribution of $A$. brasilense $\mathrm{Cd}$ in soil. However, when the soil was very dry bacteria infiltrated and in sand, where the adsorption forces are limited or negligible, movement of $A$. brasilense Cd was dependent on water flow.

Since the degree of adsorption between bacteria and soil particles is broadly related to the soil surface area and to the surface charge properties of the particles, the colloidal fraction (clay and organic matter) is the most important soil component with respect to adsorption (Marshall, 1971). The net electrical charge of the clay surfaces, as well as the surfaces of bacteria are negative (Santoro \& Stotzky, 1968). However, clay particles can possess positively charged areas to which bacteria will adsorb (Marshall, 1968; Peele, 1936). Our results indicate that, as for soil bacteria, addition of clays or organic matter to sand resulted in strong adsorption of $A$. brasilense $\mathrm{Cd}$ to the soil formed. Adsorption reached a maximum at a relatively low clay and organic matter content. At low pH values, the positive charge density on the edges of clay particles increases (Marshall, 1971). Increased bacterial adsorption with decreased $\mathrm{pH}$ was observed by Peele (1936) for both Azotobacter chroococcum and Bacillus cereus. We obtained similar results for $A$. brasilense $\mathrm{Cd}$. The growing wheat root decreases the $\mathrm{pH}$ of its surroundings by proton extrusion (Bashan \& Levanony, 1988). Thus the partial failure of Azospirillum species to efficiently colonize grass roots in some cases (Albrecht et al., 1983; Bashan, 1986a, b) may be partially attributed to this phenomenon, since decrease of the $\mathrm{pH}$ of the surrounding soil results in increased adsorption capability, thus preventing the migrating bacteria from reaching the roots.

A. brasilense Cd migrates towards synthetic attractants in the soil (Bashan, 1986c), as well as towards its natural attractant, the living root (Bashan \& Levanony, 1987). The site of the attractants in the soil determined the site of most of the bacterial population. If sufficient water were provided for bacterial motility, the adsorption forces created by the soil had only a marginal effect on the bacteria. Therefore, it can be concluded that the motility force, induced by attractants, is stronger than the adsorption force created by soil particles.

Soil flooding has rarely been tested with respect to bacterial adsorption, and it appeared that flooding did not affect adsorption (Lowendorf, 1980, Vandecaveye, 1927). Although Azospirillum species were isolated regularly as one of the main $\mathrm{N}_{2}$-fixing bacteria from wet-land rice roots and soil, bacterial adsorption to mud was not evaluated (Watanabe et al., 1979). The 
increase in $A$. brasilense Cd adsorption in flooded soil, shown in this study, probably reflects multiplication of the bacteria.

It is proposed that clay minerals enhance survival of bacteria in the soil by protection from UV irradiation, desiccation, antibiotic production and predator-prey interactions (Marshall, 1980). Data on survival of $\boldsymbol{A}$. brasilense obtained by several microbiological and precise immunological assays revealed that this species survived poorly in soil in the absence of plants, both in the field and in the greenhouse (Albrecht et al., 1983; Bashan \& Levanony, 1987; Gaskins et al., 1984; Smith et al., 1984), decreasing to very low numbers after less than $15 \mathrm{~d}$. However, Germida (1986), using a dilution technique on non-specific medium, isolated substantial numbers of the same species for prolonged periods. In the presence of plants or peat, survival of inoculated $A$. brasilense Cd was prolonged (Albrecht et al., 1983; Sadasivam et al., 1986), the bacteria surviving for several months (Albrecht et al., 1983; Bashan et al., 1987). The data presented here give further evidence of poor survival times of $A$. brasilense $\mathrm{Cd}$ in three types of soils and extended survival in peat inoculants.

In conclusion, one can say that although $A$. brasilense $\mathrm{Cd}$ is a typical rhizosphere bacteria, and no important phase in the soil per se has yet been found, it shares some of its soil adsorption characteristics with soil bacteria. However, unlike soil bacteria, $A$. brasilense $\mathrm{Cd}$ can overcome soil adsorption by its own motility through the soil to its target plant.

This study was written in memory of the late Mr Avner Bashan and was partially supported by an Eshkol fellowship from the Ministry of Science and Development, Israel to the senior author. We thank G. Richter-Levin for technical assistance and S. Dolberg from Fenizia Co. at Yeruham Crater for donating pure quartz sand. Y. Bashan is incumbent of the William T. Hogan and Winifred T. Hogan Career Development Chair.

\section{REFERENCES}

Albrecht, S. L., Gaskins, M. H., Milam, J. R., SCHANK, S. C. \& SMITH, R. L. (1983). Ecological factors affecting survival and activity of Azospirillum in the rhizosphere. In Azospirillum II, Experientia Supplementum, 48, pp. 138-148. Edited by W. Klingmüller. Basel: Birkhäuser Verlag.

BASHAN, Y. (1986a). Enhancement of wheat root colonization and plant development by Azospirillum brasilense Cd following temporary depression of the rhizosphere microflora. Applied and Environmental Microbiology 51, 1067-1071.

BASHAN, Y. (1986b). Alginate beads as synthetic inoculant carriers for the slow release of bacteria that affect plant growth. Applied and Environmental Microbiology 51, 1089-1098.

BaShaN, Y. (1986c). Migration of the rhizosphere bacteria Azospirillum brasilense and Pseudomonas fluorescens towards wheat roots in the soil. Journal of General Microbiology 132, 3407-3414.

Bashan, Y. \& Levanony, H. (1985). An improved selection technique and medium for the isolation and enumeration of Azospirillum brasilense. Canadian Journal of Microbiology 31, 947-952.

Bashan, Y. \& LeVANONY, H. (1987). Horizontal and vertical movement of Azospirillum brasilense $\mathrm{Cd}$ in the soil and along the rhizosphere of wheat and weeds in controlled and field environments. Journal of General Microbiology 133, 3473-3480.

BashaN, Y. \& LeVANONY, H. (1988). Interaction between Azospirillum brasilense $\mathrm{Cd}$ and wheat root cells during early stages of root colonization. In Azospirillum IV: Genetics, Physiology, Ecology, pp. 166-173. Edited by W. Klingmüller. Berlin, Heidelberg \& New York: Springer Verlag.

Bashan, Y., Levanony, H. \& Klein, E. (1986).
Evidence for a weak active external adsorption of Azospirillum brasilense Cd to wheat roots. Journal of General Microbiology 132, 3069-3073.

Bashan, Y., LeVANONY, H. \& Ziv-Vecht, O. (1987). The fate of field inoculated Azospirillum brasilense $\mathrm{Cd}$ in wheat rhizosphere during the growing season. Canadian Journal of Microbiology 33, 10741079.

Bitton, G., Lahav, N. \& Henis, Y. (1974). Movement and retention of Klebsiella aerogenes in soil columns. Plant and Soil 40, 373-380.

DANIELS, S. L. (1980). Mechanisms involved in sorption of microorganisms to solid surfaces. In Adsorption of Microorganisms to Surfaces, pp. 7-58. Edited by G. Bitton \& K. C. Marshall. New York: John Wiley.

Foster, R. C. (1986). The ultrastructure of the rhizoplane and the rhizosphere. Annual Review of Phytopathology 24, 211-234.

Gaskins, M. H., Albrecht, S. L. \& Milam, J. R. (1984). Survival of root associated bacteria in the rhizosphere. In Advances in Nitrogen Fixation Research, p. 52. Edited by C. Veeger \& W. E. Newton. The Hague: Martinus Nijhoff.

Germida, J. J. (1986). Population dynamics of Azospirillum brasilense and its bacteriophage in soil. Plant and Soil 90, 117-128.

Griffin, D. M. \& QUAIL, G. (1968). Movement of bacteria in moist, particulate systems. Australian Journal of Biological Sciences 21, 579-582.

LeVanony, H., Bashan, Y. \& Kahana, Z. E. (1987). Enzyme-linked immunosorbent assay for specific identification and enumeration of Azospirillum brasilense $\mathrm{Cd}$ in cereals roots. Applied and Environmental Microbiology 53, 358-364. 
LOWENDORF, H. S. (1980). Factors affecting survival of Rhizobium in soil. Advances in Microbial Ecology 4, 87-124.

LYNCH, J. M. \& BRAGG, E. (1985). Microorganisms and soil aggregate stability. Advances in Soil Science 2, 133-171.

MARSHALL, K. C. (1967). Electrophoretic properties of fast- and slow-growing species of Rhizobium. Australian Journal of Biological Sciences 20, 429-438.

MARSHALL, K. C. (1968). Interaction between colloidal montmorillonite and cells of Rhizobium species with different ionogenic surfaces. Biochimica et biophysica acta 156, 179-186.

MARShal, K. C. (1971). Sorptive interactions between soil particles and microorganisms. In Soil Biochemistry vol. 2, pp. 409-445. Edited by A. D. McLaren \& J. J. Skujins. New York: Marcel Dekker.

MARSHALL, K. C. (1975). Clay mineralogy in relation to survival of soil bacteria. Annual Review of Phytopathology 13, 357-373.

MARShall, K. C. (1980). Adsorption of microorganisms to soils and sediments. In Adsorption of Microorganisms to Surfaces, pp. 317-329. Edited by G. Bitton \& K. C. Marshall. New York: John Wiley.

Marshall, K. C. \& Bitton, G. (1980). Microbial adhesion in perspective. In Adsorption of Microorganisms to Surfaces, pp. 1-5. Edited by G. Bitton \& K. C. Marshall. New York: John Wiley.

MUDD, S. \& MUDD, E. B. H. (1924). The penetration of bacteria through capillary spaces. Journal of Experimental Medicine 40, 633-645.

Parke, J. L., Moen, R., Rovira, A. D. \& Bowen, G. D. (1986). Soil water flow affects the rhizosphere distribution of a seed-borne biological control agent Pseudomonas fluorescens. Soil Biology and Biochemistry 18, 583-588.

Patriquin, D. G., Döbereiner, J. \& JaIN, D. K. (1983). Sites and processes of association between diazotrophs and grasses. Canadian Journal of Microbiology 29, 900-915.
Peele, T. C. (1936). Adsorption of bacteria by soils. Cornell Agricultural Experiment Station, memoir no. 197.

Ravikovitch, S. (1981). The Soils of Israel, Formation, Nature and Properties. Tel Aviv: Hakibbutz Hameuchad. (In Hebrew.)

RubentsChik, L., Roisin, M. B. \& Bieljansky, F. M. (1936). Adsorption of bacteria in salt lakes. Journal of Bacteriology 32, 11-31.

Sadasivam, K. V., Negl, M. \& Tilak, K. V. B. R. (1986). Survival of Azospirillum brasilense and Azotobacter chroococcum in organic-amended soil-based carriers. Zentralblatt für Microbiologie 141, 567570.

SANTORo, T. \& STOTzKy, G. (1968). Sorption between microorganisms and clay minerals as determined by the electrical sensing zone particle analyzer. Canadian Journal of Microbiology 14, 299-307.

Siala, A., Hill, I. R. \& Gray, T. R. G. (1974). Population of spore-forming bacteria in an acid forest soil, with special reference to Bacillus subtilis. Journal of General Microbiology 81, 183-190.

SMith, R. L., Schank, S. C., Milam, J. R. \& BALTENSPERGER, A. A. (1984). Responses of Sorghum and Pennisetum species to the $\mathrm{N}_{2}$-fixing bacterium Azospirillum brasilense. Applied and Environmental Microbiology 47, 1331-1336.

THOMPSON, J. A. (1980). Production and quality control of legume inoculants. In Methods of Evaluating Biological Nitrogen Fixation, pp. 489-533. Edited by F. J. Bergersen. New York: John Wiley.

VANDECAVEYE, S. C. (1927). Effect of moisture, temperature, and other climatic conditions on $R$. leguminosarum in the soil. Soil Science 23, 355362.

Watanabe, I, Barraquio, W. L., De Guzman, M. R. \& CABRERA, D. A. (1979). Nitrogen-fixing (acetylene reduction) activity and population of aerobic heterotrophic nitrogen-fixing bacteria associated with wetland rice. Applied and Environmental Microbiology 37, 813-819. 